\title{
A STUDY OF BIDIRECTIONAL RELATIONSHIP BETWEEN DIABETES MELLITUS AND PERIODONTAL DISEASES IN CHILDREN
}

\author{
Mona Nagy", Nagwa Khattab ${ }^{* *}$, Basma Abd-El-Moez ${ }^{* * *}$ and Wafaa Khairy ${ }^{* * * *}$
}

\begin{abstract}
Although periodontitis does not belong to clinical manifestations of any type of diabetes mellitus, it is still being labeled as "the sixth chronic complication of diabetes. It has been confirmed that, in individuals with diabetes, there is about a three times higher risk of periodontitis. Thus, diabetes is considered to be a predisposing factor for periodontitis. In the diabetic patients, the periodontal disease develops at a younger age than in the healthy population. The aim of this study was to prove the bidirectional relationship between periodontal diseases and diabetes type 1 in children. Patients and Methods: this study was conducted on 40 children with age range from 8-13 years, for evaluation of periodontal diseases "Gingival Index (GI), Plaque Index (PI) and Clinical Attachment Loss (CAL)" were used, and "Glycosylated hemoglobin (HbA1c \%)" for the evaluation of blood glucose level and after application of the dental treatment program the patients were reevaluated after 3 months, 6months and 9months. Results: the results show that both periodontal diseases and diabetes type 1 had a bidirectional relationship.
\end{abstract}

\section{INTRODUCTION}

Type 1 diabetes mellitus is a chronic metabolic disease of an autoimmune origin with early manifestation predominantly in the childhood ${ }^{1-4}$.

Among the inflammatory disorders, periodontal disease-PD represents gram-negative anaerobic infections that involve tooth supporting tissues, (gingiva, alveolar ligament, root cementum, and alveolar bone $)^{5}$.
Some studies show relationship between the duration of diabetes and severity of periodontitis ${ }^{6,7}$. On the other hand, it was confirmed that there is a negative effect of periodontitis on blood glucose levels. This is due to an increased insulin resistance of tissues in reaction to systemic inflammatory mediators ${ }^{8}$. There was a presumption that treatment of periodontitis results in an improved metabolic control of diabetes ${ }^{8}$. Although some earlier studies did not support this hypothesis ${ }^{9-11}$.

\footnotetext{
* Assistant Lecturer, Pediatric and Community Dentistry Department, Faculty of Dentistry, Minia University,

** Professor of Pediatric and Community Dentistry Department, Faculty of Dentistry, Minia University,

*** Professor of Pediatrics, Faculty of Medicine, Minia University,

***** Professor of Microbiology, Faculty of Medicine, Minia University.
} 


\section{PATIENTS AND METHODS}

This study included 40 children who were previously diagnosed as T1DM patients according to $\mathrm{ADA}^{12}$. They were selected from the diabetes outpatients' clinic, Maternal and Children Minia University Hospital. Their ages range from $8-13$ years and both sexes were presented.

After fulfillment of inclusion criteria the selected patients were divided into two groups, each group with different degree of periodontal alteration;

Group I: included 20 patients with good controlled-diabetes.

Group II: included 20 patients with poor controlled diabetes.

\section{Study design:-}

After the agreement of the patient on the informed consent, all our patients were subjected to:

I. Thorough history taking (age, sex, residence, duration of diabetes, presence of any complication of diabetes, History of any dental consultation in the last 6 months).

II. Clinical examination (Anthropometric measurement "'weight, height, and body-mass index (BMI)", Systematic examination "chest, heart and abdomen", Intraoral examination 'Gingival index GI, Plaque index PI, Clinical attachment loss CAL").

III. Special investigations (Glycosylated hemoglobin $(\mathrm{HbA} 1 \mathrm{c} \%)$, Renal and liver function tests.

IV. Dental treatment program (Dental program involved both curative and preventive parts Curative was carried out to meet all child's treatment needs and included dental prophylaxis and providing restorative care for children. Preventive part included mechanical and chemical control of periodontal diseases: Health education (mechanical control)A-Tooth brushing, B-Flossing (Chemical control): Topical antimicrobial agent application (Cuteca "oral solution") in the clinic, and then how to applicate oral solutions three times daily.
V. Patient's re-evaluation (after 3monthes, 6monthes and 9monthes).

\section{RESULTS}

Table (1) shows that group I (good controlled) had significant lower gingival index scores than group II (poor controlled) at the base and at $3^{\text {rd }}$ month of the study, where $(\mathrm{p}=0.03)$. On the other hand, there were insignificant difference between them at $6^{\text {th }}$ months, $9^{\text {th }}$ months of follow up periods where $(\mathrm{p}>0.05)$. As regard separate groups, there were significant reduction of GI score at different periods of follow up in both of them where $(\mathrm{p}=0.001)$ for both.

TABLE (1): Comparison between the studied groups as regard GI at different follow up periods

\begin{tabular}{|c|c|c|c|}
\hline & Group I & Group II & P value \\
\hline Follow up period & Mean \pm SD & Mean $\pm S D$ & \\
\hline At base & $1.7 \pm 0.3$ & $1.9 \pm 0.3$ & $0.03 *$ \\
\hline At $3^{\text {rd }}$ month & $1.3 \pm 0.3$ & $1.6 \pm 0.4$ & $0.03 *$ \\
\hline At $6^{\text {th }}$ month & $1.01 \pm 0.2$ & $1.2 \pm 0.4$ & 0.1 \\
\hline At $9^{\text {th }}$ month & $0.6 \pm 0.3$ & $0.8 \pm 0.4$ & 0.1 \\
\hline P value & $0.001 *$ & $0.001 *$ & \\
\hline
\end{tabular}

${ }^{*} p<0.05$ is statistically significant

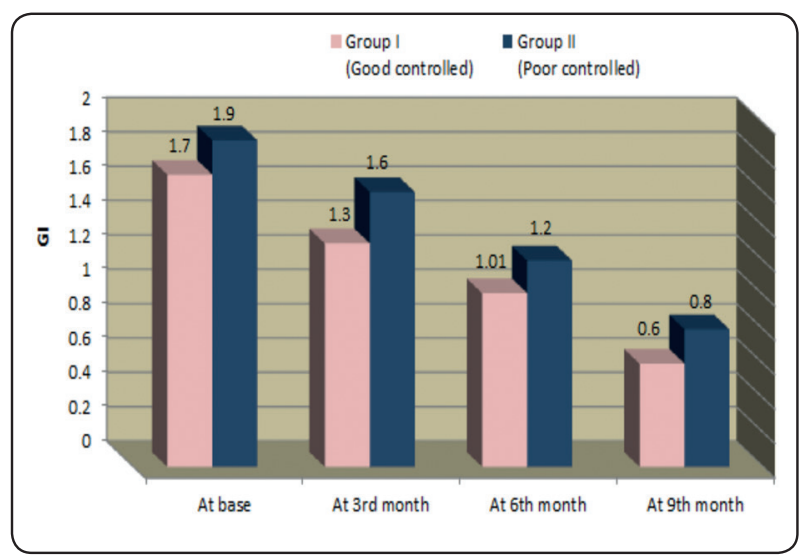

Fig. (1): Comparison between the studied groups as regard GI at different follow up periods 
According to the plaque index(PI), there was insignificant difference between different groups during the whole study periods but on the other hand, there was significant improvement in each group in the plaque index through the whole periods of the study until $9^{\text {th }} \mathrm{ms}(\mathrm{p}>0.001)$ (Table 2).

TABLE (2): Comparison between group I and II as regard Plaque Index (PI) scores at different follow up periods

\begin{tabular}{|c|c|c|c|}
\hline $\begin{array}{c}\text { PI } \\
\text { Follow up period }\end{array}$ & $\begin{array}{c}\text { Group I } \\
\text { Mean } \pm \text { SD }\end{array}$ & $\begin{array}{c}\text { Group II } \\
\text { Mean } \pm \text { SD }\end{array}$ & P value \\
\hline At base & $1.8 \pm 0.3$ & $2 \pm 0.3$ & 0.2 \\
\hline At 3 ${ }^{\text {rd }}$ month & $1.2 \pm 0.3$ & $1.4 \pm 0.4$ & 0.09 \\
\hline At 6 $^{\text {th }}$ month & $0.8 \pm 0.1$ & $1.04 \pm 0.4$ & 0.1 \\
\hline At 9 th month & $0.3 \pm 0.2$ & $0.5 \pm 0.4$ & 0.2 \\
\hline P value & $0.001 *$ & $0.001 *$ & \\
\hline
\end{tabular}

$* p<0.05$ is statistically significant

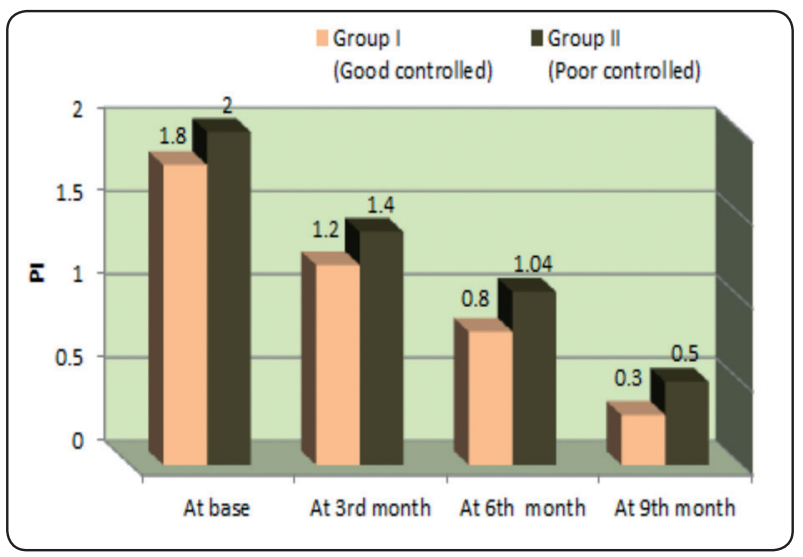

Fig. (2): Comparison between group I and II as regard Plaque Index (PI) scores at different follow up periods

In this table the clinical attachment level (CAL) had insignificant difference between groups during the whole study periods. Concerning separate groups there were significant results of $\mathrm{CAL}$ at different periods of follow up (Table 3).
TABLE (3): Comparison between group I and II as regard Clinical Attachment Level (CAL) scores at different follow up periods

\begin{tabular}{|c|c|c|c|}
\hline $\begin{array}{c}\mathrm{CAL}(\mathrm{mm}) \\
\text { Follow up period }\end{array}$ & $\begin{array}{c}\text { Group I } \\
\text { Mean } \pm \text { SD }\end{array}$ & $\begin{array}{c}\text { Group II } \\
\text { Mean } \pm \text { SD }\end{array}$ & $\mathrm{P}$ value \\
\hline At base & $4.5 \pm 0.6$ & $4.5 \pm 0.6$ & 0.9 \\
\hline At $3^{\text {rd }}$ month & $3.5 \pm 0.6$ & $3.6 \pm 0.5$ & 0.7 \\
\hline At $6^{\text {th }}$ month & $2.4 \pm 0.6$ & $2.5 \pm 0.7$ & 0.5 \\
\hline At $9^{\text {th }}$ month & $1 \pm 0.8$ & $1.7 \pm 0.8$ & 0.5 \\
\hline P value & $0.001 *$ & $0.001 *$ & \\
\hline
\end{tabular}

$* p<0.05$ is statistically significant

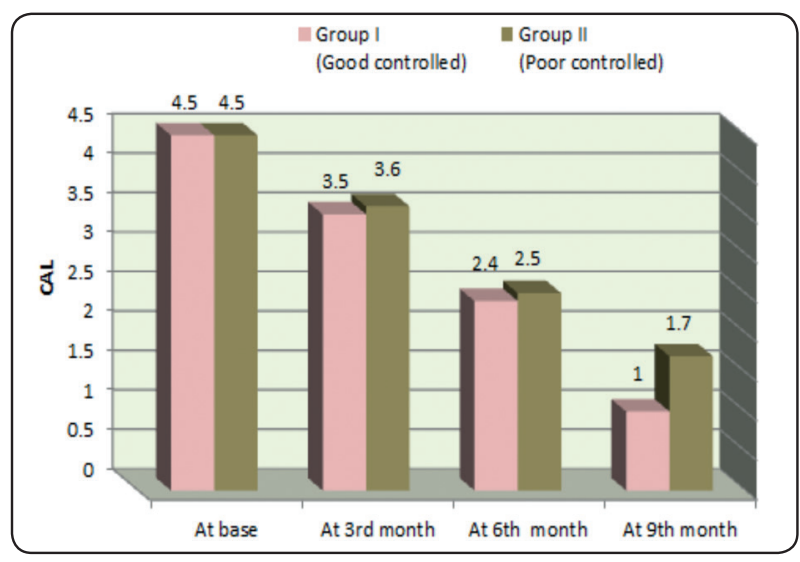

Fig. (3): Comparison between group I and II as regard Clinical Attachment Level (CAL) scores at different follow up periods

In this table group II (poor controlled group) had significant higher levels of $\mathrm{HbA}_{1 \mathrm{c}} \%$ than group I (good controlled group) at different durations of follow up (at base, at $3^{\text {rd }}$ month, $6^{\text {th }}$ month and $9^{\text {th }}$ month). Moreover, within every group there were significant reduction of $\mathrm{HbA} 1 \mathrm{c} \%$ levels at different durations of follow up where $(\mathrm{p}=0.006$ and $\mathrm{p}=0.001)$ (Table 4). 
TABLE (4): Comparison between group I and group II regarding $\mathrm{HbA} 1 \mathrm{c} \%$ at different follow up periods

\begin{tabular}{|c|c|c|c|c|c|}
\hline \multirow{2}{*}{ Follow up periods } & \multicolumn{2}{|c|}{ Group I } & \multicolumn{2}{c|}{ Group II } & \multirow{2}{*}{ P value } \\
\cline { 2 - 6 } & Range & Mean \pm SD & Range & Mean \pm SD \\
\hline At base & $6.1-7.9$ & $7.4 \pm 0.4$ & $8.1-13$ & $10.4 \pm 1.6$ & $0.001^{*}$ \\
\hline At $3^{\text {rd }}$ month & $7-11.2$ & $8.2 \pm 1.1$ & $7.9-14$ & $9.2 \pm 1.6$ & $0.001^{*}$ \\
\hline At $6^{\text {th }}$ month & $7-10.8$ & $8.1 \pm 0.9$ & $7.2-13.9$ & $8.3 \pm 1.6$ & $0.01 *$ \\
\hline At 9 $9^{\text {th }}$ month & $6.5-10.8$ & $7.5 \pm 0.9$ & $7.1-13$ & \\
\hline
\end{tabular}

${ }^{*} p<0.05$ is statistically significant

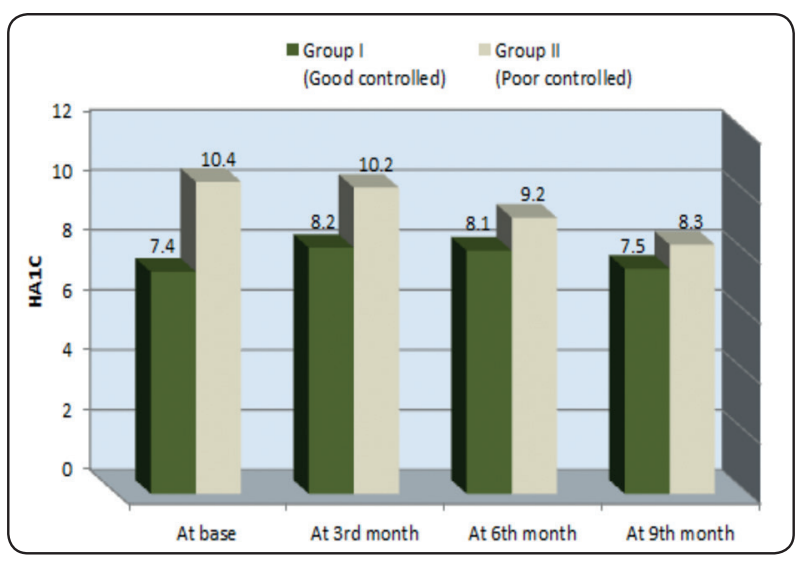

Fig. (4): Comparison between group I and group II regarding $\mathrm{HbA}_{1 \mathrm{c}} \%$ at different follow up periods

\section{DISCUSSION}

Inflammation is a central feature of both diabetes and periodontal disease, and inflammatory processes are up-regulated in periodontal tissues in diabetic patients. There is a wide range of mechanisms by which diabetes adversely affects the periodontium and, vice versa, how periodontitis influences control of diabetes, so in the current study we will discuss the results to improve the bidirectional relationship between diabetes and inflammatory periodontal diseases in children.
As regard the tested clinical parameters the results showed that the mean value of gingival index scores was significantly higher in poor controlled group than in good controlled one $(1.9 \pm 0.3$ versus $1.7 \pm 0.3)$ this finding agree with the study on a group of diabetic children aged 5-9 years, the mean value of gingival inflammation index was(1.54 \pm 0.5 versus $1.14 \pm 0.5$ ) for the control group , and also agreed with a group of diabetic children aged 10-14 years where the mean value of gingival inflammation index versus the control group was $(1.98 \pm 0.6$ and $1.17 \pm 0.5$ ) respectively ${ }^{13}$.

As regard plaque index the current results reveled that poorly controlled $(2 \pm 0.3)$ versus the good controlled group $(1.8 \pm 0.3)$. These scores were lower than Joo \& Lee $; 2007^{14}$ who recorded (3.2 \pm 1.0) for poorly controlled diabetic patients and ( 2.8 \pm 0.8 ) for good controlled diabetic children.

As regard clinical attachment level the current results reveled that we have high scores in the beginning of the study $(4.5 \pm 0.6)$ in both groups which then had a significant improvement until the $9^{\text {th }}$ month of treatment because of the reduction of the microbial causative agents of the periodontal diseases by application of the dental program treatment of the study. 
Moreover, the poor controlled group had significant higher levels of $\mathrm{HbA} 1 \mathrm{c} \%$ than good controlled group at different durations of follow up (Table 4). However, within each group there was significant reduction of $\mathrm{HbA} 1 \mathrm{c} \%$ levels at different durations of follow up. In the poor controlled group the mean $\mathrm{HbA} 1 \mathrm{c} \%$ reduced from $10.4 \pm 1.6$ to $8.3 \pm 1.6$ at the end of follow up period. This reduction was higher than that recorded in meta-analysis of five studies which reported mean reduction in $\mathrm{HbA} 1 \mathrm{c}$ of $0.40 \%$ over a follow-up period of 3-9 months after periodontal therapy ${ }^{15}$ this can be related to the dental health program that was followed by the patients in the current study.

\section{CONCLUSION}

We concluded that: All the dental clinical parameters were higher in poorly controlled diabetic group and also had higher levels of $\mathrm{HbA} 1 \mathrm{c} \%$ than good controlled group. Improvements of dental clinical parameters were associated with improvement of $\mathrm{HbA} 1 \mathrm{c} \%$.

\section{REFERENCES}

1- Gardner D. Shoback D., Greenspan's Basic and Clinical Endocrinology, McGraw-Hill Medical, San Francisco, Calif, USA, 8th edition, 105-108, 2007.

2- Angeli M., Merzon E., Valbuena L., Tirschwell D., Paris C., and Mueller B., "Environmental factors associated with childhood-onset type 1 diabetesmellitus: an exploration of the hygiene and overloadhypotheses," Archives of Pediatrics and Adolescent Medicine, 164( 8), 732-738, 2010.

3- Hober D. and Sane F.; Enteroviral pathogenesis of type 1diabetes. Discovery Medicine; 10(51): 151-160, 2010.

4- Oikarinen S., Tauriainen S., Hober D. et al; Virus antibody survey in different european populations indicates risk association between coxsackievirus B1 and type 1 diabetes. Diabetes; 63(2): 655-662, 2014.

5- Novotna M., Podzimek S., Broukal Z., Lencova E., Duskova J. , Namesti K. and Katerinska ;Periodontal
Diseases and Dental Caries in Children with Type 1 Diabetes Mellitus. Hindawi Publishing Corporation Mediators of Inflammation ;(2015) :1-8, 2015.

6- -Thorstensson H; Periodontal disease in adult insulindependent Diabetics. Swedish Dental Journal;107: 1-68, 1995.

7- Xavier A., Silva I., Costa F., and Corr^ea D.; Periodontal status in children and adolescents with type 1 diabetes mellitus. Arquivos Brasileiros de Endocrinologia e Metabologia; 53(3): 348-354, 2009.

8- Preshaw P., Alba A., Herrera D. et al; Periodontitis and diabetes: a two-way relationship. Diabetologia; 55(1):2131,2012 .

9- Salvi G., Carollo-Bittel B., and Lang N.; Effects of diabetes mellitus on periodontal and peri-implant conditions: update on associations and risks. Journal of Clinical Periodontology; 35: 398-409, 2008.

10- Llamb'es F., Silvestre F., Hern'andez A., Guiha R., and Caffesse; The effect of periodontal treatment on metabolic control of type 1 diabetes mellitus. Clinical Oral Investigations; 12(4): 337-343, 2008.

11- Tervonen T., Lamminsalo S., Hiltunen L., Raunio T., and Knuuttila M.; Resolution of periodontal inflammation does not guarantee improved glycemic control in type 1 diabetic subjects. Journal of Clinical Periodontology; 36(1): 51-57, 2009.

12- -American Diabetes Association; Diagnosis and classification of diabetes mellitus. Diabetes Care; 37:S81-S90, 2014 .

13- Orbak R., Simsek S., Orbak Z., Kavrut F., and Colak M.; The influence of type-1 diabetesmellitus on dentition and oral health in children and adolescents. YonseiMedical Journal; 49(3):357-365, 2008.

14- Joo S. and Lee J.; The comparison of inflammatory mediator expression in gingival tissues from human chronic periodontitis patients with and without type 2 diabetes mellitus. J Korean Acad Periodontol; 37:353-369, 2007.

15- Teeuw W., Gerdes V., Loos B.; Effect of periodontal treatment on glycemic control of diabetic patients, a systematic review and meta-analysis. Diabetes Care ; 33:421-427, 2010 . 